\title{
THE DIURNAL HYSTERESIS OF SNOW ALBEDO
}

\author{
By $\mathrm{K}$. MCGUfFIE and A. HENDERSON-SELLERS
}

(Department of Geography, University of Liverpool, P.O. Box 147, Liverpool L69 3BX, England)

ABSTRACT. The appearance of a diurnal hysteresis in snow albedo is a widely reported phenomenon. This note discusses the relative importance of two separate effects: surface morphosis and surface irregularities (sastrugi). It is concluded that surface morphosis is the more important effect of the two in the region of the marginal cryosphere. Surface irregularities probably are the dominant influence only on permanent cryospheric areas such as the Greenland and Antarctic plateaux.

RÉsUMÉ. L'hystéresis diurne de l'albedo de la neige. L'apparition d'une hystéresis diurne dans l'albedo de la neige est un phénomène largement décrit. Cette note discute de l'importance relative de deux effets distincts dus à la forme de la surface et aux irrégularités de la surface (sastrougi). On en conclut que la forme de la surface est l'effet le plus important des deux dans la région de la

\section{INTRODUCTION}

The response of the marginal cryosphere to climatic variations is of significance for a much greater area of the globe than the polar high latitudes (e.g. Goody, 1980; Warren, 1982). Measurements of cryospheric surface albdeo, required for verification of, and comparison with, model predictions necessitate detailed knowledge of the temporal variability of the snow surface albedo. The appearance of a diurnal variation in snow albedo is a fairly widely reported phenomenon. Early measurements (CSI, 1950) showed a diurnal variation in albedo amounting to $4 \%$ of the average Sauberer and Dirmhirn (1952) reported a strong diurnal variation said to be visible to the naked eye for several different sky conditions.

Several authors have reported the fact that snow albedo may exhibit hysteresis; the albedo in the morning being higher than in the afternoon for identical solar elevation (e.g. Hubley, 1955). We consider here several different reports of this effect and present some previously unpublished results. An attempt is made to collate the different explanations as to why albedo can be different for the same solar elevation at different times of the day and to form a concise description of the probable causes of this phenomenon.

\section{THE DIURNAL HYSTERESIS OF SNOW ALBEDO}

Reports of this phenomenon appear in Sauberer and Dirmhirn (1952) who describe strong variation in albedo with the minimum occurring in mid-afternoon. Carroll and Fitch (1981) consider the effect of surface irregularities on the snow albedo in the Antarctic. These irregularities, or sastrugi, will introduce an azimuthal dependence of albedo, the result being that the measured albedo is different for the same solar elevation angle at different times of day. Examination of a set of radiation records for Resolute (lat. $75^{\circ} \mathrm{N}$., long. $95^{\circ} \mathrm{W}$ ) (Cogley, 1983) has shown that a diurnal hysteresis of snow albedo is a fairly common phenomenon there. Typical examples are illustrated in Figure 1. This shows individual values of snow albedo derived from hourly totals of incident and reflected radiation measured over cryosphère marginale. Les irrégularités de surface ont probablement une influence prépondérante seulement dans les zones de la cryosphère permanent telles que les plateaux du Groenland et de l'Antarctique.

Zusammenfassung. Die tägliche Hysterese der albedo von Schnee. Das Auftreten einer täglichen Hysterese in der Albedo von Schnee ist eine weithin beobachtete Erscheinung. Diese Notiz behandelt die relative Bedeutung zweier getrennter Einflussgrössen: Gestalt und Unregelmässigkeiten (Sastrugi) der Oberfläche. Es wird gefolgert, dass die Oberflächengestalt der von beiden wichtigere Effekt im Gebiet der randlichen Kyrosphäre ist. Oberflächliche Unregelmässigkeiten haben vermutlich nur in permanent eisbedeckten Gebieten wie den Plateaubereichen von Grönland und Antarktika beherrschenden Einfluss.

the wavelength range 0.3-3 $\mu \mathrm{m}$. The albedo for moderate solar elevation in the morning can be seen to be noticeably higher than for the same elevation in mid-afternoon. Examination of the observed variation has shown that cycles have a $24 \mathrm{~h}$ period. This implies that the cause is not surface irregularities since these

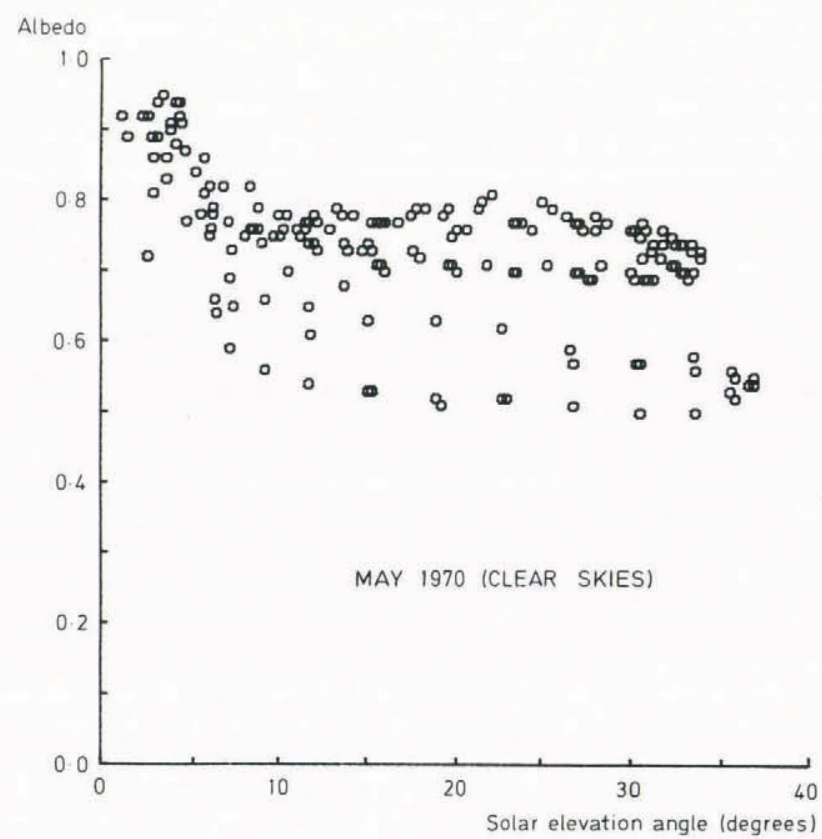

Fig. 1. Diurnal loops in observed snow albedo in clear sky conditions plotted as a function of solar elevation angle. The upper half of each loop is composed of the morning albedo values.

Upper loop 10-13 May 1970.

Lower loop 27-29 May 1970.

From data for Resolute, N.W.T., Canada.

[N.B. Measurements at low elevations may be considered to be unreliable due to deviation of the radiometer from true cosine response.] 
would result in a periodicity of $12 \mathrm{~h}$. We suggest here that the variation should be attributed to the diurnal deposition and evaporation of a hoarfrost coating on the snow surface.

Weller (1969) established that a thin hoar-frost coating could be formed during periods of low temperatures and could be removed when the temperatures increased. At Resolute the albedo is found to be highest at times of lowest temperature and lowest at times of highest temperature. For example, on 11 May 1970 at 06.00 local time, the dry-bulb temperature was $253 \mathrm{~K}$ and the surface albedo 0.77. Around the time of highest temperature that day $c .17 .00$ the albedo was 0.71 and the temperature $258 \mathrm{~K}$, although the solar elevation was the same. These observations support our theory. However we have also explored the possibility that the hysteresis effect could arise by some other means.

The hysteresis is due solely to the value of the reflected radiation being less in the afternoon than in the morning for identical solar elevation. This indicates that the effect is due to some change in the snow surface properties. The errors usually associated with radiation measurements (i.e. $\pm 5 \%$ ) are large enough to encompass the observed phenomenon. However these errors are concerned with the average deviation from the "correct" reading. It is extremely unlikely that the direction of the likely deviation from the true value for the radiation will change during the course of the day. The response of radiometers to changes in ambient temperature is insignificant for the range of temperatures involved here (personal communication from D.I. Wardle).

Yamanouchi (1983) has also examined the nature of the diurnal albedo cycle observed at Mizuho station, Antarctica. The area under the radiometer was flattened to remove the sastrugi but the diurnal loop remained (Fig. 2). Indeed at elevations of around $20^{\circ}$ the morning-afternoon contrast in albedo is observed to increase slightly. Yamanouchi (1983) suggests that this may be due to sastrugi remaining outside the cleared area.* However we feel that the remaining effect is

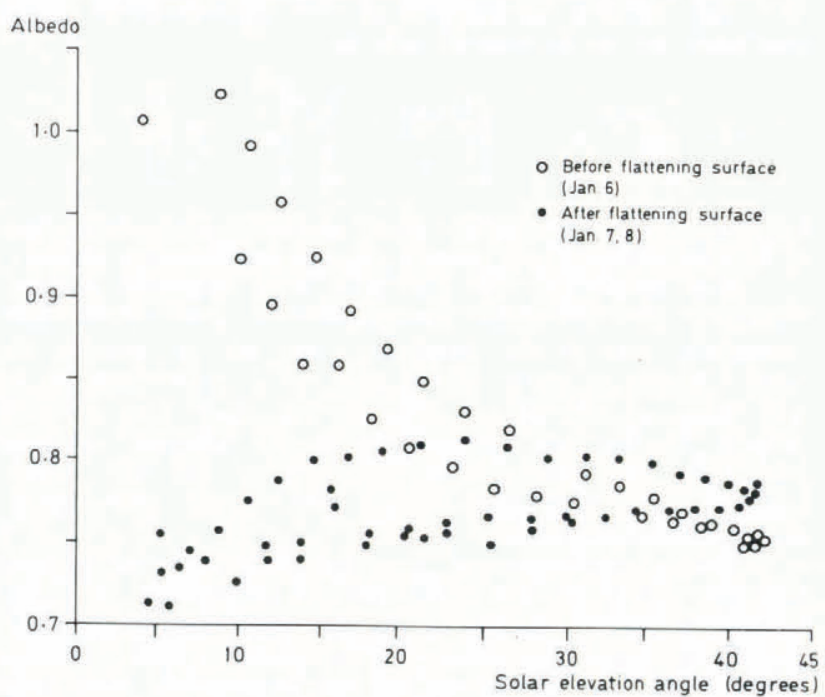

Fig. 2. Clear-sky surface albedos plotted as a function of the solar elevation angle for Mizuho, Antarctica. The two curves compare the observations made before and after flattening of the snow under the radiometer (after Yamanouchi, 1983).

*Yamanouchi does not state how large an area was cleared. more probably due to a change in the microphysical properties of the snow surface, namely the diurnal sublimation of a frost coating on the surface, i.e. the same effect as we suggest is operating at Resolute.

\section{SUMMARY}

It is clear that the diurnal hysteresis in snow albedo is due to at least two separate factors:

1. Macroscopic surface irregularities (sastrugi)

2. Microscopic morphosis of the surface during the course of the day.

Sastrugi will affect the albedo irrespective of location but the effect of hoar frost will be dependent on the strength of the diurnal cycle of solar irradiance and temperature (Weller, 1969). It is suggested that the dominant mechanism will be dependent on the geographical situation of the observation station and the frost effect will be most important and prevalent in regions where the diurnal cycle in irradiance is large. This will be predominantly in the lower latitudes where the presence of a cryosphere is marginal and hence the albedo of even greater climatic importance. It is important that both types of effects and their latitudinal relative magnitudes be noted when measurements of snow albedo are examined, especially where the measurements are not temporally detailed.

\section{REFERENCES}

Carroll, J.J., and Fitch, B.W 1981. Effects of solar elevation and cloudiness on snow albedo at the South Pole. Journal of Geophysical Research, Vol. 86, No. C65, p. 5271-76.

Cogley, J.G., and others. 1983. Cloud and radiation climatology at Resolute, Canada $\left(75^{\circ} \mathrm{N}\right)$, [by] J.G. Cogley, A. Henderson-Sellers, and K. McGuffie. Preprint volume, fifth Conference on Atmospheric Radiation, October 31-4 November 1983, Baltimore, Maryland. Boston, Mass., American Meteorological Society, p.
287-90.

CSI. 1950. Cooperative Snow Investigations, Corps of Engineers, Analysis Units. Albedo of the snow surface as related to weathering factors and stage of the season. Research Note, South Pacific Division, Corps of Engineers, U.S. Army.

Goody, R.M. 1980. Polar processes and world climate (a brief review). Monthly Weather Review, Vol. 108, No. 12, p. $1935-42$.

Hubley, R.C. 1955. Measurements of diurnal variations in snow albedo on Lemon Creek Glacier, Alaska. Journal of Glaciology, Vol. 2, No. 18, p. 560-63.

Sauberer, R., and Dirmhirn, I. 1952. Der Strahlungshaushalt horizontaler Gletscherflachen auf dem Hohen Sonnblick. Geografiska Annaler, Arg. 34, Ht. 3-4, p. $261-90$.

Warren, S.G. 1982. Ice and climate modelling: an editorial essay. Climatic Change, Vol. 4, No. 4, p. $329-40$.

Weller, G.E. 1969. The heat and mass balance of snow dunes on the central Antarctic plateau, Journal of Glaciology, Vol. 8, No. 53, p. 277-84.

Yamanouchi, T. 1983. Variations of incident solar flux and snow albedo on the solar zenith angle and cloud cover, at Mizuho Station, Antarctica, Journal of the Meteorological Society of Japan, Vol. 61, No. 12, p. 879-893. 